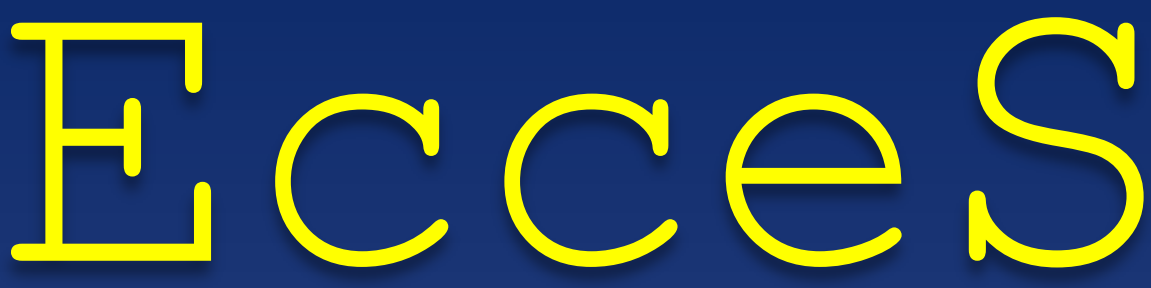

Economics, Social, and Development Studies

POSISI PENDUDUK KOTA MAKASSAR DALAM MENUNJANG

PEMBANGUNAN EKONOMI

Abdul Rahman dan Nur Rahmi Hamzah

EFISIENSI BELANJA PEMERINTAH DI SEKTOR PENDIDIKAN DAN KESEHATAN

DI PROVINSI SULAWESI SELATAN

Rapiuddin dan Bahrul Ulum Rusydi

STRUKTUR EKONOMI DAN POLA PEMBANGUNAN DAERAH

DI KAWASAN MAMMINASATA

Husni Mubarak dan Hasbiullah

PENGARUH PENGELUARAN PEMERINTAH DAN UPAH MINIMUM REGIONAL (UMR) TERHADAP TINGKAT PARTISIPASI ANGKATAN KERJA DI KOTA MAKASSAR

Ikhwan dan Siradjuddin

PENGARUH TENAGA KERJA DAN PENGELUARAN PEMERINTAH TERHADAP PERTUMBUHAN EKONOMI KOTA MAKASSAR

Irmayanti dan Aulia Rahman Bato

FAKTOR-FAKTOR YANG MEMENGARUHI PRODUKSI JAGUNG DI DESA TANAH TOWA KECAMATAN KAJANG KABUPATEN BULUKUMBA

Kamaluddin dan Andi Faisal Anwar

ANALISIS PENENTUAN SEKTOR UNGGULAN DAN PERUBAHAN STRUKTUR EKONOMI KABUPATEN JENEPONTO TAHUN 2011-2015

Syaripuddin dan Abdul Wahab 


\section{Ecces}

Economics, Social, and Development Studies

VOLUME 4 NOMOR 1 JUNI 2017

POSISI PENDUDUK KOTA MAKASSAR DALAM MENUNJANG

PEMBANGUNAN EKONOMI

Abdul Rahman dan Nur Rahmi Hamzah

EFISIENSI BELANJA PEMERINTAH DI SEKTOR PENDIDIKAN DAN KESEHATAN DI PROVINSI SULAWESI SELATAN

Rapiuddin dan Bahrul Ulum Rusydi

STRUKTUR EKONOMI DAN POLA PEMBANGUNAN DAERAH DI KAWASAN MAMMINASATA

Husni Mubarak dan Hasbiullah

PENGARUH PENGELUARAN PEMERINTAH DAN

UPAH MINIMUM REGIONAL (UMR) TERHADAP TINGKAT PARTISIPASI

ANGKATAN KERJA DI KOTA MAKASSAR

Ikhwan dan Siradjuddin

PENGARUH TENAGA KERJA DAN PENGELUARAN PEMERINTAH TERHADAP PERTUMBUHAN EKONOMI KOTA MAKASSAR

Irmayanti dan Aulia Rahman Bato

FAKTOR-FAKTOR YANG MEMENGARUHI PRODUKSI JAGUNG DI DESA TANAH TOWA KECAMATAN KAJANG KABUPATEN BULUKUMBA

Kamaluddin dan Andi Faisal Anwar

ANALISIS PENENTUAN SEKTOR UNGGULAN DAN PERUBAHAN STRUKTUR EKONOMI KABUPATEN JENEPONTO TAHUN 2011-2015

Syaripuddin dan Abdul Wahab 


\title{
STRUKTUR EKONOMI DAN POLA PEMBANGUNAN DAERAH DI KAWASAN MAMMINASATA
}

\author{
Husni Mubarak ${ }^{1}$ \\ Hasbiullah $^{2}$
}

\begin{abstract}
ABSTRAK
Penelitian ini bertujuan untuk menganalisis struktur ekonomi dan pola pembangunan daerah di kawasan Mamminasata. Data yang digunakan adalah data sekunder yang bersifat tahun (time series) dari tahun 2011-2015. Adapun teknis analisis yang digunakan menggunakan Tipologi Klassen dan Indeks Williamson. Hasil penelitian menunjukkan bahwa daerah-daerah di Kawasan Mamminasata diklasifikasikan menjadi 2, yaitu daerah maju tapi tertekan dan daerah yang telatif tertinggal. Sedangkan hasil penghitungan Indeks Williamson menunjukkan bahwa keitmpangan antar daerah di Kawasan Mamminasata secara umum meningkat dan terjadi ketimpangan yang cukup tinggi.
\end{abstract}

Kata kunci: Pembangunan, Ketimpangan, Pertumbuhan Ekonomi, Tipologi Klassen, Indkes Williamson, Mamminasata

\section{PENDAHULUAN}

Pembangunan merupakan proses multidimensional yang meliputi perubahan struktur sosial, perubahan dalam sikap hidup masyarakat dan perubahan dalam kelembagaan (institusi) nasional. Pengembangan ekonomi lokal bertujuan untuk mengembangkan ekonomi suatu wilayah yang berkelanjutan dengan mengoptimalkan pemanfaatan sumber daya lokal guna pertumbuhan ekonomi wilayah, peningkatan kesejahteraan masyarakat, pengurangan kesenjangan antar kelompok masyarakat, antar sektor dan antar wilayah (Bappenas, 2010).

Salah satu strategi pembangunan yang seringkali digunakan untuk memacu perkembangan ekonomi dan pembangunan daerah adalah dengan upaya regionalisasi. Regionalisasi dipahami sebuah konsep mengintegrasikan beberapa daerah yang berada di dekata CBT, dengan tujuan untuk mempercepat akselerasi dan perkembangan daerah-daerah yang terintegrasi tersebut. Selain itu, regionalisasi daerah juga dharapakan mampu memantik munculnya geliat ekonomi daerah-daerah yang ada di sekitarnya.

1 Universitas Islam Negeri Alauddin Makassar

2 Universitas Islam Negeri Alauddin Makassar, bahrul.rusydi@uin-alauddin.ac.id 
Dalam beberapa tahun tahun terakhir, terdapat suatu konsep regionalisasi terhadap beberapa daerah yang berada di sekitar Kota Makassar. Daerah-daerah tersebut adalah Maros, Sungguminas (Gowa) dan Takalar. Akronim dari regionalisasi daerah-daerah tersebut adalah "Maminasata".

Secara teori, sukses tidaknya strategi regionalisasi daerah tersebut bergantung pada pola dan struktur ekonomi dari masing-masing daerah yang ada di kawasan tersebut. Selain itu, secara teori permasalahan utama yang dihadapi ketika menerapkan strategi regionalisasi tersebut adalah kekhawatiran munculnya ketimpangan antar daerah dalam kawasan tersebut.

Realitas yang terjadi dalam pengamatan penulis, menunjukkan kecenderungan terjadinya kedua hal tersebut. Oleh karena itu, maka penelitian ini bertujuan untuk melakukan analisa terhadap pola dan struktur ekonomi daerahdaerah yang termasuk dalam kawasan Maminasata. Selain itu, perkembangan tingkat ketimpangan juga akan dianalisis guna melihat potensi keberhasilan dari regionalisasi kawasan Maminasata tersebut.

\section{TINJAUAN PUSTAKA}

\section{Teori Pembangunan Ekonomi}

Pembangunan ekonomi daerah adalah suatu proses dimana pemerintah daerah dan masyarakatnya mengelola sumberdaya-sumberdaya yang ada dan membentuk suatu pola kemitraan antara pemerintah daerah dengan sektor swasta untuk menciptakan suatu lapangan kerja baru dan merangsang perkembangan kegiatan ekonomi dalam wilayah tersebut.

\section{Teori Pertumbuhan Ekonomi}

Menurut Sadono Sukirno, pertumbuhan ekonomi adalah perubahan tingkat kegiatan ekonomi yang berlaku dari tahun ke tahun. Suatu perekonomian dikatakan mengalami pertumbuhan apabila tingkat kegiatan ekonomi lebih tinggi daripada yang telah dicapai pada periode waktu sebelumnya sedangkan laju pertumbuhan ekonomi adalah kenaikkan dalam Produk Regional Bruto (PDRB), tanpa memandang apakah kenaikkan tersebut lebih besar atau lebih kecil daripada tingkat pertumbuhan penduduk. Pertumbuhan ekonomi adalah proses 
kenaikkan output perkapita dalam jangka panjang, dalam hal ini ada tiga aspek yang perlu diperhatikan yaitu proses, output perkapita dan jangka panjang.

Pertumbuhan ekonomi adalah suatu "proses", bukan suatu gambaran ekonomi pada suatu saat atau yang menunjukan adanya perekonomian berkembang atau berubah dari waktu ke waktu dimana penekanannya pada perkembangan atau perubahan itu sendiri. Perubahan ekonomi berkaitan dengan "Output Perkapita", ada dua sisi yang perlu diperhatikan disini yaitu sisi output total (GDP) dan sisi jumlah penduduknya. Output perkapita adalah output total dibagi jumlah penduduk. Aspek ketiga dari definisi pertumbuhan ekonomi adalah perspektif waktu jangka panjang. Suatu perekonomian akan tumbuh apabila dalam jangka panjang mengalami kenaikkan output perkapita (Boediono, 1992).

\section{Disparitas Antar Wilayah dan Daerah}

Ketimpangan pembangunan antar wilayah merupakan aspek yang umum terjadi dalam kegiatan ekonomi suatu daerah. Ketimpangan ini pada dasarnya disebabkan oleh adanya perbedaan kandungan sumberdaya alam dan perbedaan kondisi geografi yang terdapat pada masing - masing wilayah. Akibat dari perbedaan ini, kemampuan suatu daerah dalam mendorong proses pembangunan juga menjadi berbeda. Karena itu, tidaklah mengherankan bilamana pada setiap daerah biasanya terdapat wilayah maju (Development Region) dan wilayah terbelakang (Underdevelopment Region). Terjadinya ketimpangan antar wilayah ini membawa implikasi terhadap tingkat kesejahteraan masyarakat antar wilayah. Karena itu, aspek ketimpangan pembangunan antar wilayah ini juga mempunyai implikasi pula terhadap formulasi kebijakan pembangunan wilayah yang dilakukan oleh Pemerintah Daerah.

\section{METODE PENELITIAN}

Analisis yang di gunakan pada penelitian ini adalah Analisis Tipologi Klassen dan Indeks Williamson. Analisis Tipologi Klassen adalah analisis yang digunakan untuk mengetahui gambaran tentang pola dan struktur pertumbuhan ekonomi masing-masing daerah, Tipologi Klassen pada dasarnya membagi daerah berdasarkan dua indikator utama yaitu pertumbuhan ekonomi daerah dan pendapatan perkapita daerah. Indeks Williamson adalah untuk mengukur ketimpangan antar wilayah/daerah. 
Analisis pola dan struktur pertumbuhan ekonomi digunakan analisis Tipologi Klassen seperti yang ditunjukkan dalam Tabel 1.

Tabel 1 Klasifikasi Tipologi Klassen Pendekatan Daerah

\begin{tabular}{|c|c|c|}
\hline PDRB Perkapita & \multirow{2}{*}{ ydi > yni $(+)$} & \multirow{2}{*}{ ydi < yni (-) } \\
\hline Laju Pertumbuhan & & \\
\hline rdi > rni (+) & $\begin{array}{l}\text { Daerah maju dan } \\
\text { tumbuh cepat }\end{array}$ & $\begin{array}{l}\text { Daerah berkembang } \\
\text { cepat tapi tidak maju }\end{array}$ \\
\hline rdi < rni (-) & $\begin{array}{l}\text { Daerah maju tapi } \\
\text { tertekan }\end{array}$ & $\begin{array}{l}\text { Daerah } \\
\text { tertinggal }\end{array}$ \\
\hline
\end{tabular}

Keterangan :

rdi = laju pertumbuhan antar kabupaten

rni = laju pertumbuhan total PDRB Kawasan Maminasata

ydi = pendapatan perkapita antar Kabupaten

yni = pendapatan perkapita Kawasan Maminasata

Tingkat disparitas pendapatan di Kawasan Maminasata dihitung dengan angka Indeks Williamson. Indeks Williamson digunakan untuk menentukan besarnya ketimpangan pendapatan. Metode ini diperoleh dari perhitungan pendapatan regional perkapita dan jumlah penduduk masing-masing daerah. Jika nilai indeks Williamson mendekati nol, maka tingkat kesenjangan distribusi pendapatan semakin kecil (semakin merata). Sebaliknya, jika nilai indeks Williamson semakin jauh dari nol maka kesenjangan semakin melebar. Indeks ketimpangan regional ini diformulasikan sebagai berikut :

$$
I W=\sqrt{\sum_{i=1}^{i}(Y i-Y)^{2}(f i n)} / Y
$$

Keterangan :

$I W=$ Nilai ketimpangan pendapatan di kawasan maminasata

$\mathrm{Yi}=$ PDRB perkapita antar kabupaten

$\mathrm{Y} \quad=$ PDRB perkapita kawasan mamminasata

$\mathrm{fi}=$ Jumlah penduduk antar kabupaten

$\mathrm{n}=$ = Jumlah penduduk kawasan mamminasata

Formula Indeks Williamson menggunakan PDRB perkapita dan jumlah penduduk dimana nilai yang diperoleh antara nol dan satu atau $(0<\mathrm{W}<1)$. Dengan 
indikator bahwa apabila semakin kecil nilai Indeks Williamson maka menunjukkan ketimpangan yang semakin rendah begitu pula sebaliknya semakin besar angka Indeks Williamson menunjukkan ketimpangan yang semakin tinggi.

\section{HASIL DAN PEMBAHASAN}

Dalam penelitian ini penulis menggunakan analisis Tipologi Klassen untuk mengetahui gambaran tentang pola dan struktur pertumbuhan ekonomi pada masing-masing daerah. dan Analisis Indeks Williansom untuk mengukur ketimpangan di suatu wilayah atau daerah.

\section{Pola dan Struktur Ekonomi di Kawasan Mamminasata}

Untuk mengetahui klasifikasi daerah didasarkan kepada dua indikator utama yaitu pertumbuhan ekonomi dan pendapatan atau produk domestik regional bruto per kapita. Dengan menentukan rata-rata produk domestik regional bruto (PDRB) per kapita sebagai sumbu horizontal, sedangkan daerah per kabupaten dibagi menjadi empat golongan yaitu kabupaten yang cepat maju dan cepat tumbuh, kabupaten maju tapi tertekan, kabupaten yang berkembang cepat dan kabupaten yang relatif tertinggal. (Sjafrizal, 1997; Mudrajat Kuncoro dan Aswandi, 2002).

Tabel 2. Analisa Tipologi Klassem Kawasan Maminasata

\begin{tabular}{|l|l|l|}
\hline $\begin{array}{l}\text { Laju } \\
\text { Pertumbuhan }\end{array}$ & ydi $>$ yni $(+)$ & ydi $<$ yni $(-)$ \\
\hline rdi $>$ rni $(+)$ & $(-)$ & $(-)$ \\
\hline rdi $<$ rni $(-)$ & Makassar, Maros & Takalar, Gowa \\
\hline
\end{tabular}

Dari tabel di atas dapat diketahui bahwa ada dua kabupaten yang termasuk daerah yang maju tapi tertekan yakni kabupaten Maros dan Kota Makassar Dimana Kabupaten yang memiliki pendapatan perkapita lebih tinggi di bandingkan dengan Rata-rata kawasan Mamminasata. Tetapi laju pertumbuhannya lebih rendah dibandingkan dengan Rata-rata Kawasan Mamminasata. Kabupaten yang termasuk daerah yang relatif tertinggal yakni Kabupaten Gowa dan kabupaten Takalar dimana Kabupaten yang memiliki tingkat 
pertumbuhan ekonomi dan pendapatan perkapita lebih rendah dibandingkan dengan Rata-rata Kawasan Mamminasata.

Dari hasil penelitian tersebut dapat diketahui bahwa di Kawasan Mamminasata selama priode tahun 2011-2015 dapat di simpulkan bahwa pola dan struktur ekonomi di Kawasan Mamminasata terdepat beberapa daerah yang termasuk daerah maju tapi tertekan diantaranya kota Makasssar dan Maros kedua daerah tersebut dikatakan maju tapi tertekan karena daerah-daerah yang relatif maju tetapi dalam beberapa tahun terakhir laju pertumbuhannya menurun akibat tertekannya kegiatan utama daerah yang bersangkutan. Walaupun daerah ini merupakan daerah telah maju tetapi dimasa mendatang diperkirakan pertumbuhannya tidak akan begitu cepat, walaupun potensi pembangunan yang dimiliki pada dasarnya sangat besar. Kota Makassar dan Maros tidak termasuk daerah maju dan tumbuh cepat karena laju pertumbuhanya mengalami penurunan dari tahun sebelumnya dan potensi yang di miliki kedua daerah tersebut belum di manfaatkan dengan baik.

Daerah yang relatif tertinggal yaitu Kabupaten Takalar dan Kabupaten Gowa kedua daerah tersebut dikatakan daerah tertinggal karena daerah yng mempunyai tingkat pertumbuhan dan pendapatan per kapita yang berada dibawah rata-rata dari seluruh daerah yang berada di Kawasan Mamminasata. Ini berarti bahwa baik tingkat kemakmuran masyarakat maupun tingkat pertumbuhan ekonomi di daerah ini masih relatif rendah. Tetapi hal ini tidak berarti bahwa didaerah ini tidak akan berkembang di masa mendatang. Melalui pengembangan sarana dan prasarana perekonomian daerah berikut tingkat pendidikan dan pengetahuan masyarakat setempat diperkirakan daerah ini secara bertahap akan dapat pula mengejar ketertinggalannya.

Kedua daerah tersebut tidak termasuk daerah maju dan tumbuh cepat dan daerah maju tapi tertekan karena kedua daerah tersebut memilik laju pertumbuhan dan pendapatan per kapita masih rendah dikarnakan belum megoptimalkan potensi-potensi daerah yang di miiki oleh kedua daerah tersebut. Untuk lebih jelasnya dapat dilihat dari gambar di bawah ini.

\section{Tingkat Ketimpangan antar Kabupaten di Kawasan Mamminasata}

Analisis Indeks Williamson di gunakan untuk mengukur seberapa besar ketimpangan pembangunan ekonomi antar kabupaten di Kawasan Mamminasata. 
Indeks ini memiliki arti jika nilai Indeks Williamson mendekati 0 , artinya ketimpangan kecil atau lebih merata dan jika mendekati 1 ketimpangannya besar atau melebar.

Tabel 3. Indeks Williamson antar kabupaten di Kawasan Mamminasata Tahun 2011- 2015

\begin{tabular}{|c|c|}
\hline Tahun & Indeks Williansom \\
\hline 2011 & 0,879 \\
\hline 2012 & 0,872 \\
\hline 2013 & 0,895 \\
\hline 2014 & 0,885 \\
\hline 2015 & 0,877 \\
\hline
\end{tabular}

Hasil analisis Indeks Williamson untuk kawasan Mamminasata menunjukkan seperti yang tercantum pada Tabel 3 tersebut. Terlihat bahwa nilai Indeks Williamson mengalami fluktuasi selama periode pengamatan penelitian. Namun demikian, secara umum ketimpangan cukup besar karena nilai Indeks Williamson yang lebih condong ke nilai 1 .

Kondisi tersebut mudah dipahami, karena adanya beberapa faktor yang menjadi penyebab. Pertama, perbedaan sektor potensial yang mendukung perkembangan daerah. Kota Makassar misalnya, mengandalkan perdagangan dan jasa dalam memacu pertumbuhan ekonominya. Berbeda dengan daerah lainnya yang masih mengandalkan sektor pertanian, yang mana notabene kurang memberikan nilai tambah terhadap akselerasi dan perkembangan ekonomi.

\section{KESIMPULAN}

Berdasarkan analisis data yang dilakukan dan pembahasan yang telah dikemukakan, maka diperoleh kesimpulan sebagai berikut:

1. Bahwa pengklasifikasian kabupaten/kota berdasarkan pertumbuhan ekonomi dan PDRB perkapita di Kawasan Mamminasata. Memakai alat analisis Tipologi Klassen dengan pendekatan daerah menujukkan kabupaten/kota terbagi menjadi empat klasifikasi yang ada. Akan tetapi 
hanya ada dua klasifikasi Pada periode 2011-2015 di Kawasan Mamminasata. Sebanyak dua kabupaten yang termasuk daerah maju tapi tertekan yaitu Kota Makassar dan Kabupaten Maros. Dan daerah yang relatif tertinggal yaitu kabupaten Gowa dan Takalar.

2. Ketimpangan yang terjadi di Kawasan Mamminasata periode 2011-2015 antar kabupaten pada periode tersebut terjadi ketimpangan yang cukup tinggi dan hal ini menujukkan semakin melebarnya ketimpangan di Kawasan Mamminasata. Rata-rata angka Indeks Williamson di Kawasan Mamminasata adalah sebesar 0,885.

\section{DAFTAR PUSTAKA}

Afonso, Antonio dan Miguel st. Aubyn. Non-parametric Approaches to Education and Health Efficiency in OECD Countries. Journal of Applied Economics, Vol III No. 002. 2005.

Cross Country Efficiency of Secondary Education Provisnsion : A Semi Paramertic Analysis with Nondiscreationary input, 2005.

Arikunto, Suharsimi. Prosedur Penelitian Suatu Pendekatan Praktik. Jakarta : Rineka Cipta, 2002.

Basir, Muhammad Paly. Pengukuran Efisiensi dan Produktivitas Usaha Tani, Makassar : Alauddin University Press, 2011.

Boediono. Ekonomi Mikro. Yogyakarta : BPFE, 1982.

Badan Pusat Statistik Provinsi Sulawesi Selatan, 2015.

Charnes, A, WW Cooper and E Rhodes, Measuring the efficiency of Decision Maing Units. European Journal of Operational Research 2, North : Holland Publising Company, 1978.

Cooper, William, Lawrence M. Seiford and Joe Zhu. Chapter 1 : Data Envelopment Analysis : History, Model and Interpretations.

Daniel, Setyo Budi . Efisiensi Relatif Puskesmas-Puskesmas di Kabupaten Pati Tahun 2009, Tesis MPKP FE UI, 2010.

Departemen Agama RI, Al Qur'an dan Terjemahannya. Jakarta: Yaysan Al Furqan, 2008.

Dumairy. Perekonomian Indonesia, Jakarta: Erlangga, 1996.

Erniwati, dkk, Refleksi 5 Tahun Otonomi Awards. Makassar: FIPO, 2013.

Fattah, Nanang. Ekonomi dan Pembiyaan Pendidikan. Bandung: PT Remaja Rosdakarya, 2000.

Firda, Asnita Sebayang. Kinerja Kebijakan Fiskal Daerah di Indonesia Pasca Crisis. Jurnal Fakultas Ekonomi Universitas Islam Bandung, Jurnal Ekonomi Pembangunan Vol. 10 No. 3, 2005. 
Halim. Manajemen Keuangan Daerah, Yogyakarta; Edisi Revisi : BPFE, 2008.

Hasbullah, Otonomi Pendidikan : Kebijakan Otonomi Daerah dan Implikasinya Terhadap Penyelenggaraan Pendidikan. Jakarta : Rajawali Pres, 2010.

Kementrian Kesehatan Republik Indonesia, 2014

Lena, Dina Pertiwi. Efisiesi Pengeluaran Pemerintah Daerah di Provinsi Jawa Tengah. Jurnal Ekonomi Pembangunan Vol.12 No.2 : Yogyakarta, 2007.

Mardiasmo. Akuntansi Sektor Publik. Andi : Yogyakarta, 2004.

Muhmidayeli. Filsafat Pendidikan. Bandung: PT Refika Aditama, 2011.

Noor, Isran. Politik Otonomi Daerah untuk Penguatan NKRI. Kutai Kartanegara: Seven Strategic Studies, 2012.

Purwantoro, Nugroho, Efektitas Kinerja Pelabuhan dengan data Envelopment Analysis (DEA), Manajemen Usahawan Indonesia No. 05,Th XXXIII, 2004

Qomaruddin, Saleh dkk. Asbabun Nuzul, Bandung: CV Diponegoro, 2011.

Setyo, Daniel Budi, Efisisiensi Relatif Puskesmas-Puskesmas di Kabupaten Pati Tahun 2009, Tesis MPKP FE UI, 2010.

Sudirman, Wayan. Kebijakan Fiskal dan moneter : Teori \& Empirikal. Jakarta: Kencana Prenadamedia Group, 2011.

al-Syaebani, Omar Mohammad al-Toumy. Falsafah Pendidikan Islam. Jakarta: Bulan Bintang, 1979.

Syakir Kurnia, Akhmad. Model Pengukuran Kinerja dan Efisiensi Publik M Metode Free Disposable Hull (FDH). Jurnal Ekonomi Pembangunan Vol. 11 No. 2, 2006.

Tirtarahajardja, Umar \& La Sulo. Pengantar Pendidikan. Jakarta: PT Rineka Cipta, 2015.

Undang-Undang RI No 32 Tahun 2004 Tentang Pemerintahan Daerah

Undang-Undang RI No 23 Tahun 1992 Tentang Kesehatan

Undang-Undang Otonomi Daerah. Jakarta : Pustaka Pergaulan, 2004.

Wijaya, HAW. Penyelenggaraan Otonomi di Indonesia. Jakarta: PT Raja Grafindo Persada, 2005.

Yani, Ahmad. Hubungan Keuangan antara Pemerintah Pusat dan Daerah di Indonesia. Jakarta: Rajawali Pers, 2009.

Zainal, Yasman Basri dan Subri Mulyadi. Keuangan Negara dan Analisis Kebijakan Utang Luar Negeri, Jakarta: PT Raja Grafindo, 2009. 


\section{E C C E S}

Economics, Social, and evelopment Studies

Jurusan IImu Ekonomi

Fakultas Ekonomi dan Bisnis Islam UIN Alauddin

Kampus II Jl. SIt Alauddin No.36 Samata Sungguminasa-Gowa Telp (424835)

Email: ecces@uin-alauddin.ac.id

Aturan penulisan Jurnal IImu Ekonomi Fakultas Ekonomi dan Bisnis Islam UIN Alauddin Makassar adalah sebagai berikut:

1. Artikel harus berupa tulisan asli, merupakan hasil penelitian maupun kajian dalam bidang ekonomi terapan dan belum pernah dipublikasikan di media manapun serta bebas dari unsur-unsur plagiarisme.

2. Artikel ditulis dalam Bahasa Indonesia dengan memenuhi kaidah EYD Bahasa Indonesia.

3. Sistematika penulisan:

a. Bagian awal: judul, nama penulis (dituliskan lengkap tanpa gelar), abstrak yang tidak lebih dari 300 kata dan diketik dengan satu spasi yang berisi latar belakang, tujuan, metodologi, dan hasil penelitian.

b. Bagian utama: pendahuluan, tinjauan teoritis dan pustaka, metode penelitian, hasil dan pembahasan, serta kesimpulan.

c. Bagian akhir: daftar pustaka, dan lampiran.

4. Judul artikel ditulis dengan menggunakan huruf kapital.

5. Teknik penulisan:

a. Alinea baru dimulai pada ketikan kelima pada batas tepi kiri. Antar alinea tidak diberi tambahan spasi.

b. Penggunaan kata asing ditulis dengan menggunakan huruf miring (italic).

c. Batas pengetikan: tepi kiri tiga $\mathrm{cm}$, tepi kanan dua $\mathrm{cm}$, tepi atas tiga $\mathrm{cm}$, dan tepi bawah dua $\mathrm{cm}$.

d. Tabel, gambar, dan ilustrasi lainnya diberikan judul, nomor, dan sumber yang jelas.

e. Sumber pustaka ditulis nama-tahun (nama belakang penulis, tahun penerbitan). Nama penulis harus tepat sama dengan yang tercantum dalam daftar pustaka.

6. Naskah diketik dengan MS Word, spasi satu, ukuran font 11, huruf Arial, dengan panjang minimum-maksimum 15-20 halaman (A4).

7. Tulisan harus dikirim paling lambat 1 bulan sebelum penerbitan jurnal ke email jurnal Ecces atau diserahkan langsung ke tim pengelola dalam bentuk CD.

8. Jurnal Ecces terbit 2 kali dalam setahun, yaitu Juni dan Desember.

9. Email jurnal Ecces: jurnalecces@gmail.com 


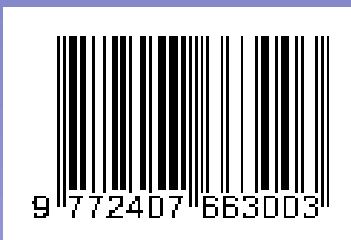

